\title{
Bacterial Contamination of White Coats among Medical Personnel- A Cross Sectional Study in Kolhapur, India
}

\author{
P. Arun Kumar (D), Roma A. Chougale* and Indireddy Sinduri \\ Department of Microbiology, D.Y. Patil Medical College, Kolhapur - 416 005, Maharashtra, India.
}

\begin{abstract}
To minimize exposure to hazardous biological materials, all doctors, nurses, technicians and in general all the healthcare personnel as well as researchers wear a knee-length, long-sleeved, elastic-cuffed laboratory coat while working with hazardous materials. A white coat provides a protective layer and can be easily removed if contaminated. White coats act as mechanical vectors in transmission of pathogenic and non-pathogenic bacteria to the people who are associated with health care workers. A total of 120 specimens were collected by using sterile cotton swabs. Of these, $88(73 \%)$ white coats were contaminated. At the same time, a pre-validated and semi-structured questionnaire (containing questions regarding usage of white coat, purpose, hygiene, and perception about contamination of white coats, etc) was distributed. Gram positive cocci $64(72.72 \%)$ were isolated more than gram negative bacilli 24 (27.28\%). Most of the tested antibiotics showed resistance to isolated gram positive and gram negative bacteria. $10(41.66 \%)$ isolates of gram negative bacilli were resistant to extended spectrum beta-lactamases (ESBL) and $10(6.4 \%)$ of staphylococcal isolates showed Methicillin resistance. Therefore, a much more attention to wear a clean white coat should be required.
\end{abstract}

Keywords: White coat, ESBL, MRSA, Gram negative bacilli, Gram Positive cocci

*Correspondence: neetiroma@gmail.com; +91 9890275056

(Received: March 22, 2020; accepted: May 24, 2020)

Citation: Kumar PA, Chougale RA, Sinduri I. Bacterial Contamination of White Coats Among Medical Personnel- A Cross Sectional Study in Kolhapur, India. J Pure Appl Microbiol. 2020;14(2):1405-1411. doi: 10.22207/JPAM.14.2.38

(C) The Author(s) 2020. Open Access. This article is distributed under the terms of the Creative Commons Attribution 4.0 International License which permits unrestricted use, sharing, distribution, and reproduction in any medium, provided you give appropriate credit to the original author(s) and the source, provide a link to the Creative Commons license, and indicate if changes were made. 


\section{INTRODUCTION}

White coat to a person in medical field is just like what skin is to a human ${ }^{1}$. To protect their street clothes from contamination, medical and laboratory professionals wear a knee length over coat which is known as white coat ${ }^{2}$. It is a symbol of professionalism, identification ${ }^{3}$, trust and respect from others, where white color indicates purity and goodness ${ }^{1,3-7}$. In many medical institutions "White Coat Ceremony" is conducted to welcome MBBS students to the medical field ${ }^{8,9}$.

To minimize exposure to hazardous biological materials, proper clothing and/or personal protective equipment (PPE) should provide reasonably complete coverage of the skin and clothing. Most of the Scientists and Doctors prefer to wear a knee-length, long-sleeved, elasticcuffed white coat while working with hazardous materials. A white coat provides a protective layer and can be easily removed if contaminated. Reusable white coats should be cleaned regularly ${ }^{14}$ White coats are worn by all medical practitioners. However, when, how and where they wear and wash their white coats varies from person to person and even between different institutions ${ }^{5}$. Healthcare workers and students commonly wear white coats in restaurants, libraries, super-marts etc and also keep them in vehicles and office ${ }^{3,8,11}$. Pediatricians and Psychiatrists generally prefer not to wear white coats in order to decrease anxiety among these categories of patients ${ }^{7,12}$. Transient increase in blood pressure of patient by just seeing a doctor in a white coat is known as "white coat syndrome"12.

Despite practicing strict infection control measures, white coats act as mechanical vectors in transmission of pathogenic and non-pathogenic bacteria to the people who are associated with health care workers ${ }^{1}$. Healthcare- associated

Table 1. Number of Isolated Bacteria

\begin{tabular}{lccc}
\hline & \multicolumn{2}{c}{ Isolated no } & \multirow{2}{*}{$\begin{array}{c}\text { Total isolated } \\
\text { bacteria }\end{array}$} \\
\cline { 2 - 3 } & Male & Female & \\
\hline $\begin{array}{l}\text { Gram Positive } \\
\text { cocci }\end{array}$ & 43 & 21 & $64(72.72 \%)$ \\
$\begin{array}{l}\text { Gram Negative } \\
\text { bacilli }\end{array}$ & 15 & 09 & $24(27.28 \%)$ \\
$\begin{array}{l}\text { Total(n) } \\
\text { (65.90\%) }\end{array}$ & $\begin{array}{c}58 \\
(34.09 \%)\end{array}$ & 88 \\
& & &
\end{tabular}

infections (HAI's) pose a great risk of morbidity and mortality, as well as increased length of stay in hospital and cost of treatment ${ }^{2,6,11}$. Some antibiotic resistant strains like MRSA, which may spread among clinical and nonclinical persons, are found on white coats. ${ }^{3,5,11,13}$. This finding suggests that the health management of the hospital does not give enough relevance to the white coat use.

There is currently no literature on the contamination of white coats of medical personnel in Kolhapur city of Maharashtra, India. Hence the present study was planned in the Microbiology department of D.Y. Patil Medical College, Hospital and Research centre, Kolhapur, to detect the level and type of bacterial contamination and antibiotic susceptibility pattern of bacteria present on white coats of medical personnel and analyze the risk of spreading HAls by such contact. Moreover, we also wanted to study the medical personnel's habits of handling the coat, cleaning it and their perception towards white coat contamination.

\section{METHODOLOGY}

Specimen were collected from preclinical, para-clinical M.B.B.S students, staff nurses and resident doctors by using sterile cotton swabs moistened with sterile physiological saline. Swabs were gently rotated to the front side of the lower edge of the white coat. Swabs were labeled properly and transported immediately to the Microbiology laboratory (D.Y. Patil Hospital and Research Institute, Kolhapur).

Swabs were inoculated into MacConkey agar and Blood agar and incubated at $37^{\circ} \mathrm{C}$ for 24 hours. After incubation, growth was confirmed by colony morphology on agar plates and gram stained smears of colonies. Biochemical reactions (Catalase, Oxidase, Indole, MR, VP, Citrate, Urease, TSI etc) and Antibiotic sensitivity testing

Contaminated Not Contaminated

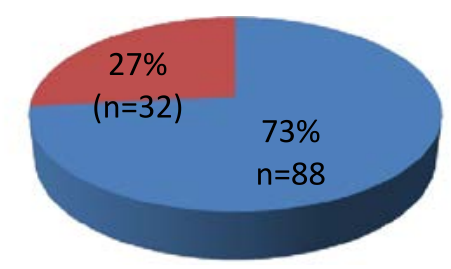

Fig. 1. Total Sample Distribution 
were performed as per the standard guidelines. Phenotypic confirmation of MRSA and ESBL was also performed as per the CLSI guidelines 2018. ${ }^{19}$ At the same time, a pre-validated and semistructured questionnaire (containing questions regarding usage of white coat, purpose, hygiene, and perception about contamination of white coats, etc) was distributed among the same 120 persons from whom the swabs were collected.

\section{RESULTS}

Total 120 samples were collected, out of these 72 were male and 48 were female (Fig. 1).

Of these 88 contaminated specimens, 64 were gram positive bacteria, 24 were gram negative bacteria. See table 1

Out of 64 gram positive cocci, 48 were CONS, 16 were $S$. aureus followed by gram negative bacilli (24). Of these, E. coli (12) were found to be more in number than the Klebsiella spp (8). Four Pseudomonas spp. were isolated. [Table 2].

Table 2. Distribution of Bacterial Isolates

\begin{tabular}{lcc}
\hline Organisms & $\begin{array}{c}\text { Isolation number } \\
(\mathrm{n}=88)\end{array}$ & Percentage \\
\hline CONS & 48 & $54.55 \%$ \\
S.aureus & 16 & $18.18 \%$ \\
E.coli & 12 & $13.64 \%$ \\
\hline
\end{tabular}

Table 3. Antibiotic Susceptibility Profile for Gram Negative Bacilli

\begin{tabular}{|c|c|c|}
\hline Antibiotics & $\begin{array}{c}\text { Sensitive } \\
(n=24)\end{array}$ & $\begin{array}{c}\text { Resistance } \\
\quad(n=24)\end{array}$ \\
\hline $\begin{array}{l}\text { Amoxicillin -Clavulanic } \\
\text { acid( } 30 \mu \mathrm{g})\end{array}$ & $22(91.66 \%)$ & $2(8.33 \%)$ \\
\hline Ampicillin $(10 \mu \mathrm{g})$ & $16(66.66 \%)$ & $8(33.33 \%)$ \\
\hline $\begin{array}{l}\text { Piperacillin-Tazobactum } \\
(100 / 10 \mu \mathrm{g})\end{array}$ & $23(95.83 \%)$ & $1(4.16 \%)$ \\
\hline Chloramphenicol $(30 \mu \mathrm{g})$ & $20(83.33 \%)$ & $4(16.66 \%)$ \\
\hline Ciprofloxacin $(5 \mu \mathrm{g})$ & $21(87.5 \%)$ & $3(12.5 \%)$ \\
\hline 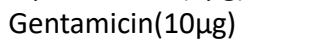 & $15(62.5 \%)$ & $9(37.5 \%)$ \\
\hline Tetracycline $(30 \mu \mathrm{g})$ & $20(83.33 \%)$ & $4(16.66 \%)$ \\
\hline Meropenem $(10 \mu \mathrm{g})$ & 18 (75\%) & $6(25 \%)$ \\
\hline Aztreonam $(30 \mu \mathrm{g})$ & $11(45.83 \%)$ & 13 (54.16\%) \\
\hline Ceftazidime $(30 \mu \mathrm{g})$ & $14(58.33 \%)$ & 10 (41.66\%) \\
\hline $\begin{array}{l}\text { Ceftazidime Caluvanic } \\
\text { acid }\end{array}$ & $14(58.33 \%)$ & $10(41.66 \%)$ \\
\hline
\end{tabular}

All the isolated gram negative bacteria were screened for Extended Spectrum betalactamases (ESBL)-by using Ceftazidime and Ceftazidime+ Caluvanic acid discs (Table 3). Of these 24 gram negative isolates 10 (41.66\%) were shown to be ESBL producers (CLSI Guidelines 2018)

Methicillin resistance Staphylococci were screened by using Cefoxitin $(30 \mu \mathrm{g})$ disc diffusion method according to the CLSI guidelines 2018*.

Table 4. Antibiotic Susceptibility profile for Gram Positive Bacteria

\begin{tabular}{lcc}
\hline Antibiotics & $\begin{array}{c}\text { Sensitive } \\
(\mathrm{n}=64)\end{array}$ & $\begin{array}{c}\text { Resistant } \\
(\mathrm{n}=64)\end{array}$ \\
\hline Erythromycin $(15 \mu \mathrm{g})$ & $38(59.75 \%)$ & $26(40.62 \%)$ \\
Clindamycin $(2 \mu \mathrm{g})$ & $38(59.75)$ & $26(40.62 \%)$ \\
Cefoxitin $(30 \mu \mathrm{g})$ & $54(84.37 \%)$ & $10(16.62 \%)$ \\
Linezolid $(30 \mu \mathrm{g})$ & $64(100 \%)$ & 00 \\
Vancomycin $(30 \mu \mathrm{g})$ & $63(98.43 \%)$ & $01(1.56 \%)$ \\
Chloramphenicol $(30 \mu \mathrm{g})$ & $62(96.87 \%)$ & $2(3.12 \%)$ \\
Tetracycline $(30 \mu \mathrm{g})$ & $52(81.25 \%)$ & $12(18.75 \%)$ \\
Gentamicin $(10 \mu \mathrm{g})$ & $51(79.68 \%)$ & $13(20.31 \%)$ \\
Ciprofloxacin $(5 \mu \mathrm{g})$ & $48(75 \%)$ & $16(25 \%)$ \\
\hline
\end{tabular}

Table 5. MRS Distribution

\begin{tabular}{lc}
\hline MRSA & $3(4.68 \%)$ \\
MRCONS & $7(10.93 \%)$ \\
\hline
\end{tabular}

\section{DISCUSSION}

Traditionally, the white coat is considered to bring credibility and dignity to the medical profession, ${ }^{20}$ but nowadays white coats harbor potential contaminants and these may play an important role in the transmission of pathogenic micro-organisms and resistant determinants.

High rate of the bacterial contamination of white coats is associated with the following factors:

Continuous shedding of infectious microorganisms by patients in hospital environment, who may constantly be in contact with hospital health care workers,

Survival of Microorganisms between 1098 days on fabrics (Cotton, Polyester etc.) ${ }^{21,22}$

Our institution is a tertiary care hospital, medical college and research institute. Medical students who work in the clinical wards indiscriminately use the white coats even outside the hospital premises. 
In our study, male participants were $60 \%$ and female participants were $40 \%$ [Fig. 1]. In the present study, $73 \%$ of the white coats which were screened were contaminated with bacteria [Fig. 2]. Our study shows a similar rate of contamination like Mwamungule et al. 2015. They conducted a study on white coats among 107 health care workers in major risky departments (Obstetrics and Gynecology, the out-patient department, Laboratory department, Intensive care unit, Medicine, Pediatrics and Surgery). Of these, they found that 94 (72.8\%) were contaminated. This study included hospital personnel except students or interns; hence they found a high rate

Table 6. Questionnaire Distribution ( $N=120)$

\begin{tabular}{|c|c|c|c|}
\hline Basic variables & $\begin{array}{c}\text { No. of white } \\
\text { coats examined }\end{array}$ & $\begin{array}{l}\text { No. of white } \\
\text { coats contaminated }\end{array}$ & $\begin{array}{l}\text { Contamination } \\
\text { rate }\end{array}$ \\
\hline \multicolumn{4}{|l|}{ 1.Gender } \\
\hline Male & 72 & 52 & $72.22 \%$ \\
\hline Female & 48 & 36 & $75 \%$ \\
\hline \multicolumn{4}{|l|}{ 2.Subjects come from } \\
\hline Home & 54 & 34 & $62.96 \%$ \\
\hline Hostel & 66 & 54 & $81.81 \%$ \\
\hline \multicolumn{4}{|l|}{ 3.Type of white coat } \\
\hline Half Sleeves & 106 & 80 & $75.4 \%$ \\
\hline Full sleeves & 14 & 08 & $57.14 \%$ \\
\hline \multicolumn{4}{|l|}{ 4.Washed by } \\
\hline Own & 61 & 56 & $91.80 \%$ \\
\hline Laundry & 59 & 32 & $54.23 \%$ \\
\hline \multicolumn{4}{|l|}{ 5. Frequency of Washing } \\
\hline Once a week & 44 & 22 & $50 \%$ \\
\hline Twice a week & 54 & 35 & $64.81 \%$ \\
\hline More than twice a week & 22 & 11 & $50 \%$ \\
\hline \multicolumn{4}{|l|}{ 6.Usage } \\
\hline Hospital & 18 & 9 & $50 \%$ \\
\hline Hospital and college & 82 & 68 & $82.92 \%$ \\
\hline Non-clinical areas & 20 & 11 & $55 \%$ \\
\hline \multicolumn{4}{|l|}{ 7. Duration of Usage } \\
\hline One hour & 1 & 0 & 0 \\
\hline Two hour & 3 & 1 & $33.33 \%$ \\
\hline More than two hour & 115 & 87 & $75.65 \%$ \\
\hline \multicolumn{4}{|l|}{ 8. Use of Disinfectant } \\
\hline Yes & 84 & 61 & $72.16 \%$ \\
\hline No & 35 & 27 & $77.14 \%$ \\
\hline \multicolumn{4}{|l|}{ 9. Last Washed } \\
\hline 2 days before & 79 & 57 & $72.15 \%$ \\
\hline 4 days before & 23 & 17 & $73.91 \%$ \\
\hline More than 4 days before & 18 & 14 & $77.77 \%$ \\
\hline \multicolumn{4}{|l|}{ 10. Practice of handling } \\
\hline Holding in hands & 10 & 6 & $60 \%$ \\
\hline In college bag pack & 11 & 5 & $45.45 \%$ \\
\hline Wear it all time & 98 & 77 & $78.57 \%$ \\
\hline \multicolumn{4}{|l|}{ 12.Practice of exchanging } \\
\hline Yes & 118 & 88 & $88 \%$ \\
\hline No & 1 & 0 & 0 \\
\hline \multicolumn{4}{|l|}{ 12. Stain Present } \\
\hline Yes & 24 & 19 & $79.16 \%$ \\
\hline No & 95 & 69 & $78.40 \%$ \\
\hline
\end{tabular}


of contamination.

Other studies have reported contamination rates of white coats ranging from $23 \%$ to $91.3 \%$ (Uneke et al. $2010^{21}$, Treakle et al. $2000^{18}$, Qaday et al. $2015^{5}$ ). This varying rate of contamination may be due to the type of the clinical facilities in which the study was conducted.

Table 1 shows that, Gram negative bacilli (27.28\%). were isolated in lesser number. This is comparable to the other findings such as A.A Akanbi et al. $2017(26.21 \%)^{26}$. In our study, E. coli were $13.63 \%$, Klebsiella spp (9.09\%) and Pseudomonas (4.54\%). All these microorganisms are frequently found in the hospital environment, but they have also been implicated as causative agents in nosocomial infections. ${ }^{26}$

As shown in Table 2 coagulase negative Staphylococci (CONS) were the most commonly isolated bacteria (54.54\%), followed by S.aureus (18.18\%). Gram positive bacteria are more frequently seen in animate and inanimate surfaces and all major implant devices used in hospitals as compared to gram negative bacteria. Our finding is similar to Trupti B. Naik et al. 2015 (54.45\%). They conducted a study on white coats among $2^{\text {nd }}$ Year MBBS students who were not frequently exposed to clinical settings and concluded that these Staphylococci may be normal commensal bacteria. Previously, CONS were considered as harmless; but nowadays, due to advances in medical technology like indwelling foreign devices such as joint prosthesis, vascular grafts etc, CONS has emerged as a potential pathogen in hospital environment. However other studies have found S.aureus as the predominant organism contaminating the white coats. (Qaday at al 20155, Saxena et al. $2013^{25}$, Banu et al. $2012^{8}$ ). This might be due to the difference in the working sites (like ICU, Wards, Accident \&Emergency department etc.) of the people on whom the study was conducted.

As seen in Table 4, all 64 Staphylococcal isolates were sensitive to Linezolid, whereas one isolate was resistant to Vancomycin (1.56\%), 2 isolates were resistant to Chloramphenicol (3.12\%) and 26 were resistant to Erythromycin (40.62\%) and Clindamycin (40.62\%). This is nearly similar to the finding of A.A Akanbi et al. 2017 (39.39\%) ${ }^{26}$. In our study, Methicillin Resistant Staphylococci were isolated from 10 isolates [Table 5]. Of these, 3 isolates (4.68\%) were MRSA and 7 (10.93\%) were
MRCONS. Our finding was lower than the study of Reza et al. 2013(18.18\%). Our study was at the tertiary care level, were our faculty is aware about antibiotic resistance and the antibiotic policy of our hospital.

As seen in table 6, we found that usage of the white coats in hospital and college is more (82.92\%), followed by volunteers (55\%) using it in non-clinical areas (canteens, tea-stalls, reading rooms, temple) and this is highly significant. This finding is similar to the findings reported by Noor et $a l^{11}$. Our study indicates that participants were not aware or do not have the knowledge that white coat harbours microorganisms that may cause nosocomial infection in patients.

Another study showed that male white coats were more contaminated than female ${ }^{3}$. However, in some studies it was found that female white coats were more contaminated than male ${ }^{11,3}$. Racheal Rettner showed that, full sleeves are more contaminated than half sleeves ${ }^{23}$. In our study, specimen from half-sleeved white coats were collected more in number than full sleeved white-coat specimen; hence, maybe they were found to be more contaminated than full-sleeved white coats. However, this data is not significant.

Most of the subjects (45\%) preferred washing their coats twice a week, however 'plateau effect' (contamination reaching Constant steady state) occurs within a week; thereafter there is no considerable variation in contamination level ${ }^{2,3,13}$. In this study we found that white coats of subjects coming from hostels were more contaminated (55\%) than those coming from home (45\%). This is statistically significant [P=0.034]. In some studies, it was shown that in people residing at home, white coats were more contaminated than those who reside at hostel indicating risk of spreading HAl to community due to improper handling of white coats in homes and traveling ${ }^{13}$. Among the subjects who used the white coats for more than 2 hours (75.65\%), the contamination rate was less than the subjects who wear it all time (78.57\%). This may be due to the fact that some subjects did not believe that white coats could harbor potential harmful pathogens that may be risky. Hence they continued to wear white coats all the time during the service and thought that white coat was a dress code or fashion statement, in and outside the hospital premises. 
In most of the volunteers who exchanged the white coats with other colleagues during the services, high $(74.57 \%)$ contamination was found; indicating that continuous usage of white coats can harbor more potential pathogens and transfer cross infection to others. White-coats of volunteers which were having more stains were heavily contaminated $(81.05 \%)$. This may be due to improper handling of syringes and blood products during the management of patients in wards, emergency services such as accidents, trauma cases etc. Regular washing with detergents and disinfectants can reduce the microbial load in white coats but sometimes the subjects forget to carry along and wash the white-coats regularly at home. Some hospitals arrange special services for laundering the white coats and keep an alarm system to remind the HCWs about washing their white coats in order to reduce the burden of microbial load in white-coats.

Indications do to improve the situation found; does not allow to carry white coats out of the hospital. Regular washing with detergents and disinfectants of the white coats should arrange by hospitals. Use 2 or more white coats will be reduce the microbial load and not allow multiple use or exchange of the white coats. Create awareness about HAls to health care workers and infection control team of the hospital to maintain strict policy about the usage of white coats

\section{CONCLUSION}

Therefore, it can be concluded that whitecoats are potential sources of cross infection. Yearly purchase of white coats and use of 2 or more coats for each person should be made compulsory. White coats should be washed at least once weekly by using a disinfectant and strong detergent. We must ban the use of white coats in non-clinical areas such a canteen, library etc.

In our study $73 \%$ of the white coats which were screened, were contaminated with bacteria. CONS (54.54\%) were isolated most, followed by S.aureus (18.18\%), E.coli (13.63\%), Klebsiella spp (9.09\%) and Pseudomonas spp (4.54\%). 10 isolates showed MRS and most of the isolates showed resistance to at least one antibiotic.

\section{Limitations}

This study only evaluates the white coats of health-care workers. Further studies are required to evaluate the detailed levels of bacterial contamination of different fomites and mandate a strict audit process and protocols to be set in place for preventing the contamination.

\section{ACKNOWLEDGEMENTS}

We would like to express our heartfelt gratitude to the laboratory technician of Krisna Diagnostics Pvt. Ltd, Kolhapur for assistance in technical work. We offer our thanks to our statisican Mrs. Manjari Desai for providing assistance in data analysis. We would like to thank the Teaching staff of Department of Microbiology, D.Y Patil Medical College, Kolhapur for their constant support and encouragement. we also thank the Nursing staff from D.Y Patil Hospital and Research institute, Kolhapur for guiding in sample collection.

\section{CONFLICT OF INTEREST}

The authors declare that there is no conflict of interest.

\section{AUTHORS' CONTRIBUTIONS}

All the authors designed the experiments, performed the experiments, analyzed the data and wrote the manuscript. All the authors read and approved the manuscript for publication (AK, RAC and IS).

\section{FUNDING}

None.

\section{ETHICS STATEMENT}

This protocol was approved by Institutional Ethical Committee (IEC), D.Y Patil Medical College, Kolhapur.

\section{DATA AVAILABILITY}

All datasets generated or analyzed during this study are included in the manuscript

\section{REFERENCES}

1. Pydi S, Panchava S, Sanikommu S. "Microbial contamination of the white coats among preclinical and clinical dental students: A comparative crosssectional study". J Indian Asoc Public Health Dent. 2015;13:193-6. https://doi.org/10.4103/23195932.159068

2. Naik TB, Upadhya A, Mane V, Biradar A. "Microbial Flora on Medical Students' White Coat and an Analysis 
of its associated factors: A Cross Sectional Study". Int Curr Microbiol App Sci. 2016;5(7):353-363. https://doi. org/10.20546/ijcmas.2016.507.038

3. Reza Robati, mohammadmehdi F, fereidoun MJ, Seyed AH. "Effect of White coat on spread of nosocomial infection"pelagiareserch library. European Journal of Experimental Biology. 2013;3(3):156-159.

4. Fernandez E. "Doctors and medical students in India should stop wearing white coats". BMJ. 2015;351:h3855. https://doi.org/10.1136/bmj.h3855

5. Qaday J, Sariko M, Mwakyoma A, Kifaro E, Mosha D, Tarimo R, Nyombi B, Shao E. "Bacterial contamination of Medical doctors and students white coats at Kilimanjaro Christian Medical Centre, Moshi, Tanzania". Int. J. Bacteriol. 2015;1-5. https://doi. org/10.1155/2015/507890

6. Surase P, Nataraj G, Kuyare S, Mehta P. "The Ever Increasing Reservoirs of Infection in Health Care Environment- Time for a Sixth Moment of Hygiene". J Assoc Physicians India. 2016;64(8):31-36.

7. Herbert A Obu, Joseph MC, Plus CM, IkechukwuO, Bismark C Eke, Uchenna E, S Agwu. "pediatrician wearing a white coat: A survey of preferences among children and their care givers". Annals of Tropical Medicine and Public Health. 2013: 508-512. https:// doi.org/10.4103/1755-6783.133699

8. Banu A, Anand M, Nagi N. "White coat as a vehicle for bacterial contamination". J. Clin. Diag. Res. 2012;6(8):1381-1384

9. https://en.wikipedia.org/wiki/White_coat_ceremony. White Coat Ceremony - wikipediaA

10. https://www.cdc.gov/mrsa/lab/index.html.a/lab/ index.html.

11. Noor F, Jayanthi RS. "The study of microbial flora on doctors white coats in tertiary care hospital in outskirts of Hyderabad, Telangana, India". Int J of Res in Med Sciences. 2016;4(7):2705-2712. https://doi. org/10.18203/2320-6012.ijrms20161936

12. Mark S. "The Doctors White coat- A Historical Perspective" AMA J. of Ethics.Virtual Mentor. 2007;9(4):310-314.

13. Susan Mwamungule, henry C, Sydney M, Geoffrey $M$, Geofreey, John B. "Conatmination of health care workers coats at university teaching hosiptal in Lusaka zambia: the nosocomial risk" M wamungule et al. J Occup Med.2015. https://doi.org/10.1186/s12995015-0077-2

14. http://www.uvm.edu/safety/laboratory_clothing.
15. Jones VA. "The white coat: why not follow suit? "JAMA, 1999;281:478. https://doi.org/10.1001/ jama.281.5.478-JMS0203-5-1

16. Neely AN. "A survey of gram-negative bacteria survival on hospital fabrics and plastics". J. Burn Care Rehabil. 2000;21:523-7. https://doi.org/10.1097/00004630200021060-00009

17. Uneke CJ, ljeoma PA. "The potential for nosocomial infection transmission by white coatsused by physicians in Nigeria: implications for improved patient-safety initiatives". World Health Popul. 2010;11:44-54. https://doi.org/10.12927/whp.2010.21664

18. Treakle AM, Thom KA, Furuno JP, et al. "Bacterial contamination of health care workers white coats". Am J Infect Control. 2009;37:101-5. https://doi. org/10.1016/j.ajic.2008.03.009

19. https://clsi.org/education/2018-ast-packages/

20. Muhadi SA, Aznamshah NA, Jahanfar S. "A cross sectional study of microbial contamination of medical students' white coat". Malays J Microbiol. 2007;3(1):35-38. https://doi.org/10.21161/ mjm.00607

21. Uneke CJ, ljeoma PA. World Health and Population. 2010;11(3):44-54. https://doi.org/10.12927/ whp.2010.21664

22. Chacko L, Jose S, Issac A, Bhat KG." Survial of nosocomial bacteria on hospital fabrics"Indian Journal of Medical Microbiology. 2003;21(4):291.

23. Rachel rettner. live science "Long sleeves on Doctors white coat may spread germs" Oct 2017. https://www. scientificaerican.co/article/lonh-sleeves-on-doctorswhite-coats-may-spread-germs.

24. Srinivasan $\mathrm{M}, \mathrm{A}$ Uma, A Vinodhkumaradithyaa, $\mathrm{S}$ Gomathi and $P$ Thirumalaikolundusubramanian. "The Medical Overcoat - Is It a Transmitting Agent for Bacterial Pathogen?" Jpn J Infect Dis. 2007;60:121-2

25. Saxena RK, Bhosale A, Kazi M, et al. "Microbial flora on aprons of Dental healthcare professionals". J. Dental \& Allied Sci. 2013;2(2):54-56. https://doi. org/10.4103/2277-4696.159284

26. Ajibola Aliu Akanbai et al., "Bacterial contamination of medical doctors' white coats as contributing factor to hospital acquired infections" Int Jour Biol Chem Sci. 2017;11(1):185-194. https://doi.org/10.4314/ijbcs. v11i1.15

27. Fernandes E. "Doctors and medical students in India should stop wearing white coats". BMJ. 351(2 015):h3855. https://doi.org/10.1136/bmj.h3855 